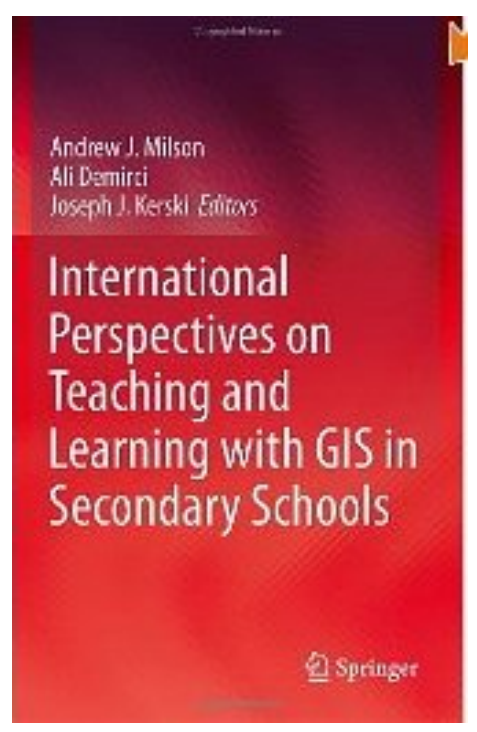

\title{
International Perspectives on Teaching and Learning with GIS in Secondary Schools
}

Editors

\author{
Andrew J. MILSON; Ali DEMIRCI;
}

Joseph J. KERSKI

\section{Reviewer}

Marsha Alibrandi, Fairfield University, Fairfield, CT, USA

\author{
Publisher \\ New York, Springer \\ Publication Year \\ 2012, XXXIX
}

Edition: First edition; Pages: 353 pages; Price: $\$ 139$ (USD) ; ISBN: Hardcover ISBN: 978-94-007-2119-7, e- ISBN: 978-94-007-2120-3

Introduction by Roger Tomlinson (1 page); 35 chapters; 66 illustrations, 24 in color; Bibliography, 20 pages; Index, 67 contributors. Foreword by Roger Tomlinson

An eagerly awaited volume edited by three GIS scholars, the new International Perspectives on Teaching and Learning with GIS in Secondary Schools is a comprehensive guide to the current state of Geographic Information Systems (GIS) in education globally. This is no small task, and its value to the GIS in education community is as broad as the book's scope. For educators, policy-makers, Geography and Teacher educators, this collection by 67 international contributors

With a foreword by Roger Tomlinson, Canadian "father" of GIS, the book commands an important niche on the library shelf of all geography educators. In a world whose histories of geographic education differ, an effort of this scope marks a significant step toward understanding one another's educational systems, commitments to geographic education, and perhaps most importantly, sets a stage for future international collaboration.

The editorial team of Milson, Demirci and Kerski garners the efforts of wellestablished GIS educators and authors. Andrew Milson, Professor of Education at the University of Texas at Arlington, co-editor of a previous volume on GIS education in 
Social Studies, brings an overview and organizational background to the wide range of contributing authors. Ali Demirci, Associate Professor of Geography at Fatih University in Istanbul, provides a deep background on GIS instruction known worldwide. Joseph Kerski, currently President of the National Council for Geographic Education in the US and Education Manager at Esri GIS, provides an inimitable world view, connection, and collaborations with several of the chapters' authors and activities.

The editors' comments can be viewed on a Springer video introduction of the book at: http://www.youtube.com/watch?v=f3PoGicD9bw\&feature=related

A uniform format for each chapter is helpful in understanding the differences in the education polities in which Geography and GIS are located. Some nations have where there is such a thing, gone so far as including GIS in the national curriculum. Others have unique GIS activities, but each participating country provides a description of that landscape. Case studies from each country provide windows into the new landscapes of learning emerging from innovative educators using geospatial tools in rather comparable ways.

Several of the contributing authors are members of the International Geographical Union, and have worked with national governments on not only geographic education, but hail from wide-ranging applications of geography and GIS. The collaborations these authors are involved in include the World Bank, the European Union, HERODOT, and EUROGEO, and among them have published some fifty volumes on various topics. Their interests range from regional geography to medical geography, climate change, civil engineering, statistical analysis, conflict resolution, meteorology, crisis mapping, HIV/AIDS epidemiology, economic development and regional planning, population geography, and spatial statistics and modeling. Several of the authors have won awards from ESRI for their significant works.

While the polities of education differ in each country, there is great value in learning about the differences and the similarities seen in this global context. Each chapter describes the context of GIS in relation to the national curriculum.

The editors asked each author to guide the reader though an overview of the context of secondary schooling in the country, an explanation of the status of GIS in each country's schools, a case illustrating the use of GIS for teaching and learning in the country, and a discussion of the prospects for GIS in the country's schools in the future (page 2). 
Book Review / International Perspectives on Teaching and Learning with GIS in Secondary Schools

At the time of publication, only 8 of the 33 nations in the book had national curricula with GIS specified. These were China, Finland, India, Norway, South Africa, Taiwan, Turkey, and the United Kingdom. Note than in such nations as the US, Canada, and Australia, where state and provincial curricula are present and comparable to the size of some nations, there can be no such national commitment. The Australian chapter addresses this directly, as well as noting an overall drop in students majoring in geography in the last decade. But the mere uniqueness of those that countries have instituted GIS at the national educational ministry level is certainly diverse, demonstrating the editors' overview that:

The global terrain of GIS in education cannot be characterized as flat. There are important differences between and within countries in terms of the context of schooling, the technological infrastructure, and the recognition of GIS as a vital tool for teaching and learning (3).

To illustrate some of the differences, selected highlights from the nations that have included GIS in the national curriculum are briefly presented here. In China, for example, "GIS courses are included in both optional and required courses in teacher preparation programs" (59). GIS was instituted into the national curriculum in 2004, and students encounter it fist in junior and senior levels, however, few students are able to use GIS unless they take the "Applications of Geographic Information Technology" as seniors, since there are few computers available. Therefore, the focus on the teacher's knowledge for demonstrating GIS is critical.

In Finland, some national grant funding yielded sufficient results to move GIS into the national curriculum. An initial project on water quality studies was followed by a multi-site grant project focused on teacher training at five school sites. Would that national policy might be moved so quickly as in a nation of five and a quarter million!

One can imagine the variations from one country to another, and perhaps the students' activities are somewhat more unifying, what with science and social studies curricula comparable internationally. The case studies make each site come alive for the reader, and all in all, with the scope and high participation of international contributors, this volume is one that certainly deserves to belong on the shelves of geography teachers and teacher educators, science teachers and teacher educators, and instructional technologies teachers and teacher educators. It would be most instructive to school administrators and policy-makers in any state, province, nation or district.

With the teaching and learning of GIS in schools now fully into its third decade, an international comparative study such as this is immensely important for the future of geographic education. This compilation is a vital work and should be read by individuals in each school district today as we enter a new landscape of learning and teaching with geospatial technologies. 